\title{
Croatian Military Chaplains Marko Hummel and Ivan Kralj in the Light of the Archival Records of the War Archives in Vienna
}

\author{
MIHA ŠIMAC* \\ - https://doi.org/10.31823/d.28.2.1 • \\ UDK: 356.363(497.5Đakovo)"18/19“ • Original Scientific Paper \\ Received: $9^{\text {th }}$ September 2019 • Accepted: $26^{\text {th }}$ May 2020
}

${ }^{*}$ Asst. Prof. Miha Šimac, Ph. D., Catholic Faculty of Theology in Ljubljana, University of Ljubljana,

Poljanska cesta 4, P. O. box 2007, 1001 Ljubljana,

Republic of Slovenia, miha.simac@teof.uni-lj.si

Summary: Several archival records and documents in the War Archives in Vienna portray the life and work of military clergy in the Habsburg armed forces. The paper presents the life and work of military chaplains from the Diocese of Bosnia or Đakovo and Srijem, Croatia, Marko Hummel and Ivan Kralj, who worked and operated in the Habsburg armed forces. Marko Hummel joined the aforementioned armed forces in the mid-19 $9^{\text {th }}$ century and performed religious services until his retirement, while Ivan Kralj served in the army for a much shorter period of time, since he supposedly had trouble with his superiors and due to the circumstances he encountered in Petrovaradin (Peterwardein). The main purpose of the following paper is to cast some light on a part of the Croatian church history that is frequently forgotten and to hopefully motivate further research of the topic.

Keywords: Austria-Hungary, military clergy, Diocese of Bosnia or Đakovo and Srijem, Ivan Kralj, Marko Hummel, War Archives, Vienna.

\section{Introduction}

In 2001, Nikola Mate Roščić (b. 1940, Grabovac) published an article on military pastoral care in Croatia titled »U službi čovjeka i mira: Vojno dušobrižništvo u Hrvatskoj « in the periodical Obnovljeni život: časopis za filozo- 
fiju i religijske znanosti. In the introduction, he conceded that the abovementioned historical topic of the Croatian church and military historiography is very poorly researched. ${ }^{1}$

Even today, this topic of the Croatian historiography has not been thoroughly researched. We have to take into account that only a few memoirs ${ }^{2}$ or war diaries of the Croatian military chaplains who served in the Habsburg armed forces before or during World War I have been preserved, since they were mainly destroyed in the time of post-war Croatia.

It is even more difficult to find fragments of chaplains' personal correspondence with their families or other chaplains who served at various battlefields. Nevertheless, in the War Archives in Vienna (Kriegsarchiv Wien), especially its fond the Apostolic Field Vicariate (k.u.k. Apostolisches Feldvikariat), we can find records and documentation of most Croatian military chaplains during World War I, their career paths, qualifications and characteristics. During my latest research in the War Archives in Vienna, I came across several documents detailing lives and careers of Croatian military chaplains Marko Hummel and Ivan Kralj.

Marko Hummel, born in Kalocsa, Hungary, served in the military of the Austrian Empire from 1851, witnessing the painful military defeats in Bohemia and Italy, and the transformation of the empire that was falling apart into a dual monarchy called the Austro-Hungarian Empire and the subsequent military reforms which shaped the Habsburg military, including its military clergy, into a military force that stood on the Serbian and Russian border in July 1914.

Despite the unstable times of the $19^{\text {th }}$ century and military setbacks, Marko Hummel decided to remain in the Habsburg armed forces until his retirement in 1892, steadily climbing up the military hierarchy to the rank of military parish priest (Militärpfarrer).

On the other hand, military chaplain Ivan Kralj from Zagreb, Croatia, never fully embraced the military lifestyle, since he left the army after several years of service and devoted himself to the pastoral work in the parish Stenjevec in the Archdiocese of Zagreb for the rest of his life.

\footnotetext{
${ }^{1} \gg$ Povijesni prikaz vojnog dušobrižništva u Hrvata ne postoji kao sustavno istraživana i predstavljena tematska cjelina. (...) Hrvatski vojni kapelani spadaju u 'povijest carskoga i kraljevskoga vojnoga dušobrižništva i apostolskog vikarijata u ratu’ pa bi to valjalo istražiti i obraditi.« See Nikola Roščić, »U službi čovjeka i mira: Vojno dušobrižništvo u Hrvatskoj«, in Obnovljeni život: časopis za filozofiju i religijske znanosti, no. 4, 2001, p. 451; p. 456.

${ }^{2}$ See also the most known diary of Franciscan Gabro Cvitanović. In: Karlo Jurišič, Gabro Cvitanović $i$ njegov ratni dnevnik: 1914-1918 (Split: Zbornik Kačić, 1984).
} 
On the basis of the Austrian archival records and other documents from the War Archives in Vienna, which have been very rarely used by Croatian historians in their researches of the Habsburg military clergy so far, I decided to write their biographies and include the information on their characteristics, virtues and also shortcomings as reported by their superiors.

The purpose of the following paper is to cast some light on a part of the Croatian church history that is frequently forgotten and hopefully motivate other Croatian historians to carry out a more thorough research of the topic.

\section{Armed Forces and the Clergy}

In 1890, Major Andrej Komel von Sočebran (1829-1892) published a book titled Organizacija vojstva (Heeres-Organisation). It included a detailed classification of military personnel, from generals and officers to military judges and officials. ${ }^{3}$ In this classification, an important place was reserved for the military chaplains who were incorporated into the Imperial Armed Forces from the $16^{\text {th }}$ century, when the first military vicar was appointed. In accordance with the development of the military, soldiers' spiritual care also gradually developed, from the presence of military chaplains in mercenary regiments to a permanent presence of military chaplains in the regular units of the Imperial Army. In 1773, the Habsburg military authorities established the Apostolic Field Vicariate on the basis of necessary organisational changes and supplementations, especially after the transformation of the Austrian Empire into the Dual Monarchy in 1868. The Apostolic Field Vicariate operated until the collapse of the Monarchy.

In 1773, the jurisdiction over the Imperial Army in times of peace and war was given to the residential bishop of Wiener Neustadt, Bishop Johann Heinrich von Kerens (1725-1792). ${ }^{4}$ He immediately appointed new vicar generals (Feldsuperiors) and 94 military chaplains for infantry and cavalry regiments. Later, the number of military chaplains even increased, since they were also assigned to the artillery. Joseph II rearranged the borders of dioceses, abolished the diocese in Wiener Neustadt, and transferred the headquarters of the Apostolic Field Vicariate to St. Pölten,

\footnotetext{
${ }^{3}$ Andrej Komel, Organizacija vojstva cesarskim in kraljevskim vojakom v podukv vprašanjih in odgovorih: Heeres-Organisation zur Belehrung des kais. und königl. Soldaten in Fragen und Antworten (Klagenfurt-Celovec, 1890), p. 1.

${ }^{4}$ Johann Heinrich von Kerens (born May 22, 1725 in Maastricht; + November 25, 1792 in Vienna) was a Jesuit, a bishop in Roermond, St. Pölten, and Wiener Neustadt. Between 1773 and 1792, he was an apostolic vicar of the Imperial Army. A short biography of Johann Heinrich von Kerens: https://gedaechtnisdeslandes.at/personen/action/show/controller/Person/?tx_gdl_gdl\%5Bperson\% $5 \mathrm{~d}=1201$ (accessed on August 29, 2019).
} 
and in 1822 to Vienna. ${ }^{5}$ The Apostolic Field Vicar (Apostolischer Feldvikar) was responsible for performing various tasks and duties and could give absolution, most frequently in relation to various matrimonial matters; in special cases, he asked the Holy See to give absolution. As a representative of military clergy, which was generally divided into military superiors and military chaplains, he was responsible for operation and supervision, and was in charge of ensuring a proper spiritual care of the Imperial Army. ${ }^{6}$

Military superiors who were appointed by the Emperor operated as deputies (Stellvertreter) of the Apostolic Field Vicar and supervised the operation of military clergy in the districts appointed to them, and they acted as advisers to the local commanding officer in all matters related to the spiritual care of the Army. ${ }^{7}$ Initially, the Aulic War Council (Hofkriegsrat) predicted the foundation of five general vicariates, but Bishop Kerens decided that this would not suffice for efficient operation. Thus, in 1774, he established nine such Military Superiorates (general vicariates). After the annexation of Galicia and Bukovina, a Military Superiorate was also founded for these two lands; in 1850, another Military Superiorate was established for Croato-Slavonian Military Frontier. Furthermore, in 1854, the spiritual care of the Imperial Austrian Navy was rearranged, which previously belonged to the Italian Military Superiorate. There was some concern about the spiritual care of sailors. Nevertheless, an independent Navy Superiorate was established due to the highest command dated December 2, 1854, and it integrated all navy chaplains. Navy chaplain Josef Toth was appointed the first Navy Superior (Marinesuperior). ${ }^{8}$

In 1855, the pay grades in the Armed Forces were rearranged. Thus, the Apostolic Field Vicar was assigned to the Grade $\mathrm{V}$ and was comparable to the rank of a major-general (Generalmajor), the second-in-command field consistorial director (Feldkonsistorialdirektor) was comparable to the rank of a lieutenant colonel, while the military superior was comparable to the rank of a major. The first consistorial secretary was first assigned to the Grade IX and was thus comparable to the rank of a captain but was reassigned to the Grade VIII in 1863 and was thus comparable to the rank of superiors. The second consistorial secretary, as well as military chaplains of the first and second class, belonged to the Grade IX, and were thus

${ }^{5}$ Jože Plut, Za pravice človeka (Ljubljana: Družina, 2002), p. 60.

${ }^{6}$ Miha Šimac, Vojaški duhovniki iz slovenskih dežel pod habsburškim žezlom (Acta Ecclesiastica Sloveniae 36), (Ljubljana: Inštitut za zgodovino Cerkve pri Teološki fakulteti, 2014), pp. 37-38 (hereafter cited as: Šimac, Vojaški duhovniki).

${ }^{7}$ Peter Steiner, Militärseelsorge in Österreich: Aufbau, Gliederung und Organisation (1848 bis 1992), (Wien: Dipl. Arbeit, 1992), p. 33 (hereafter cited as: Steiner, Militärseelsorge).

${ }^{8}$ Šimac, Vojaški duhovniki, pp. 37-38. 
comparable to the rank of a captain..$^{9}$ The military chaplains of the third class were assigned to the Grade $\mathrm{X}$ and were comparable to the rank of a first lieutenant.

Military superiors provided spiritual care to all military units, commands, hospitals, and other military establishments without their own military chaplain. In all delicate affairs, military superiors informed and consulted the Apostolic Field Vicar, and strictly followed his instructions and advice. An army military superior was assigned to each army in the time of war.

At the end of the $18^{\text {th }}$ and in the beginning of the $19^{\text {th }}$ century, the appointment of military chaplains to individual units still remained the right of the so-called $\gg$ regiment proprietors « (Inhaber). Namely, the foundations of the Imperial Army originated from the times when a wealthy nobleman gathered soldiers and assembled a regiment. Such proprietors had special privileges related to the appointment and promotion of officers. However, the Apostolic Field Vicar was not fond of such an arrangement. Bishop Kerens strived to transfer the right to nominate the priests for military chaplains to bishops of individual dioceses. A special commission was formed to realise the idea. Moreover, bishops also stood up for the improvement of financial position of military clergy. Furthermore, bishops demanded to be informed about the activities (evaluations) of every military chaplain from their diocese once a year. In 1805, the Emperor confirmed these regulations for the Austrian lands (while in Hungary this question was resolved as early as 1811!). In June 1808 , the regulation on the appointment of military chaplains was slightly supplemented. At the time, a special rescript was issued, which determined that the right to appoint the military chaplains of regiments was given to those bishops of individual dioceses from which the soldiers of individual regiments were recruited. ${ }^{10} \mathrm{In}$ his book, Bielik reports that in 1812, according to that decision, the bishop of the Diocese of Bosnia or Đakovo and Srijem had the right to appoint the military chaplain for the $53^{\text {rd }}$ infantry regiment (Baron-Hiller-Infanterie). ${ }^{11}$ Later on, the imperial rescript was supplemented several times; the last precise review of the appointment procedure was issued at the end of 1862. At the time, the Bishop of Bosnia or Đakovo and Srijem had the right to nominate the military chaplain for the $78^{\text {th }}$ (Croato-Slavonian) infantry regiment. ${ }^{12}$ The appointments and reassignments of military clergy were carried out in accordance with the needs of military service,

\footnotetext{
${ }^{9}$ Steiner, Militärseelsorge, p. 34.

${ }^{10}$ Šimac, Vojaški duhovniki, pp. 39-40.

${ }^{11}$ Emmerich Bielik, Geschichte der k.u.k. Militär-Seelsorge und des Apostolischen Feld-Vicariates, (Wien: Selbstverlag, 1901), p. 156 (hereafter cited as: Bielik, Geschichte der k.u.k. Militär-Seelsorge).

${ }^{12}$ Ibid., p. 159; p. 162.
} 
military chaplains' language skills and prior agreements between the Military Apostolic Vicariate and the Imperial War Ministry.

Military chaplains provided spiritual care to the soldiers of the Army they belonged to. They were in charge of keeping records on death, marriage and baptism, for celebrating masses, bestowing sacraments, conducting burials, hearing confessions, teaching, and preaching; additionally, they tried to keep the soldiers' morale high. They were named after the places where they served, for example navy, garrison, hospital, and regiment chaplains. They operated at various other military institutions and were also teachers of religious classes and priests at the military academies. ${ }^{13}$

To enter the active military clergy, a priest had to be younger than 40 years old, successful in theological studies, with at least three years of pastoral experience, and the knowledge of at least one more language of the Monarchy in addition to German. ${ }^{14}$ From this point of view, the Slavic priests had a certain advantage compared to those coming from the entirely German-speaking dioceses.

Military chaplains had to work in accordance with the military command. Military commanders had to evaluate and give opinions on the work of military chaplains at the end of every military year (in October). These evaluations were written in military personnel records (Conduitelisten). ${ }^{15}$ Evaluations and military personal records were generally compiled for every officer, since the military authorities preferred a good overview of the abilities and skills of their personnel. Such documents on the Habsburg military clergy between 1846 and 1890 are kept in the War Archives in Vienna, since the military clergy was also incorporated into the new evaluation and military personnel records system (Qualifikationslisten). In 1869, after the state reorganization and the military reforms, the military authorities replaced ConduiteListen with Qualifikationslisten - very detailed annual reports about officers, in which their work, knowledge, characteristics, and appropriateness for further duties or possible promotion were graded annually. These evaluations need to be read with caution, since, due to the increased bureaucratic duties, the superiors soon started using standardised formulations. In time, these evaluations began to resemble heroic descriptions of extremely competent officers, which is of course not true. According to the discussion of Istvan Deák, there was the so-called $\gg$ inflation of praise $\ll$, and so, a true insight into these evaluations has to be read between the

\footnotetext{
${ }^{13}$ Steiner, Militärseelsorge, p. 33.

${ }^{14}$ Dienstvorschrift für die Militär-Geistlichkeit vom Jahre 1887, (Wien: Kaiserlich-königlichen Hof und Staatsdrukerei, 1887), pp. 1-2.

${ }^{15}$ Bielik, Geschichte der k.u.k. Militär-Seelsorge, pp. 164-166.
} 
lines. ${ }^{16}$ Such personnel records were also kept for the military clergy, including the two military chaplains who came from the Diocese of Bosnia or Đakovo and Srijem in the $19^{\text {th }}$ and in the beginning of the $20^{\text {th }}$ century.

\section{Military Chaplains from the Diocese of Bosnia or Đakovo and Srijem}

Primary sources for research on military clergy from individual dioceses are usually diocesan yearbooks but in this case I used a different source. In 2003, the priest Msgr. Antun Jarm (1935-2013) published a book entitled Dijecezanski svećenici koji su djelovali na sadašnjem području Biskupije Đakovačke i Srijemske od 1701. do 2003. godine. ${ }^{17} \mathrm{He}$ wanted to pay tribute to the memory of all priests who worked in the area of the present-day Archdiocese and present basic data on individual priests. In the introduction, Jarm particularly emphasised that he focused only on the diocesan clergy; therefore, with rare exceptions, one cannot find records on the monks in it. The book itself is a sort of necrology of the clergy, which is chronologically and alphabetically arranged. However, the format of the necrology differs from the one we are used to. Namely, it includes more data on every priest, since the biographical data are supplemented with notes on priest's important literary works, the data on his religious services, and information on the secularisation or conversion, e.g., to the Orthodox Church. In the introduction, the author apologised for not acquiring some of the data, while some information is questionable, since different records about individual positions and reassignments appear in various accessible sources. ${ }^{18}$ In general, the book explicitly presents the life and work of the clergy in the past three centuries. The priests were not active only in their home environment but also in the Imperial Army, as can be discerned from Jarm's postscripts to biographies of individual priests. By means of Jarm's book, I composed a provisional list of military clergy in the diocese:

\begin{tabular}{|c|l|}
\hline Year of death & \multicolumn{1}{|c|}{ Surname and name } \\
\hline 1729 & Kabalin (Caballini) Marko Petar \\
\hline 1749 & Niemetz Josip \\
\hline 1753 & Jakobović Matija \\
\hline 1797 & Grdenić Bartol \\
\hline
\end{tabular}

\footnotetext{
${ }^{16}$ István Deák, Beyond Nationalism: A Social and Political History of the Habsburg Officer Corps, 18481918 (New York - Oxford: Oxford university Press, 1990), pp. 20-21.

${ }^{17}$ Antun Jarm, Dijecezanski svećenici koji su djelovali na sadašnjem području Biskupije Đakovačke i Srijemske od 1701. do 2003. godine (Đakovo: Biskupski ordinarijat, 2003), (hereafter: Jarm, Dijecezanski svećenici).

${ }^{18}$ Jarm, Dijecezanski svećenici, pp. 3-5.
} 


\begin{tabular}{|c|l|}
\hline Year of death & \multicolumn{1}{|c|}{ Surname and name } \\
\hline 1809 & Marinkovič Pashal \\
\hline 1810 & Blagajac Josip \\
\hline 1849 & Plepelić Ivan \\
\hline 1850 & Götzy (Goczy, Geci) Kristijan \\
\hline 1855 & Polczer Ivan \\
\hline 1860 & Sabolić Anton \\
\hline 1883 & Turković Franjo \\
\hline 1885 & Énekes (Enekeš) Ivan \\
\hline 1898 & Hummel Marko \\
\hline 1915 & Šimon (Simon) Stjepan \\
\hline 1917 & Gross Josip \\
\hline 1926 & Kralj Ivan \\
\hline 1935 & Novak dr. Mirko (Emmerich) \\
\hline 1942 & Bogutovac dr. Stjepan \\
\hline 1943 & Kotnik Ivan \\
\hline 1945 & Vrančić Anton \\
\hline 1956 & Adžić (Ađić) Antun \\
\hline 1957 & Marjanović Dragutin \\
\hline 1965 & Kraljić Josip \\
\hline
\end{tabular}

Source: Jarm, Dijecezanski svećenici.

Further information on religious services of military chaplains (when, in which garrison, etc.) can be found in Militärschematismus des österreichischen Kaiserthumes [sic!] of the Imperial Army and in the archival records and documentation of the War Archives in Vienna. During my last research in the War Archives, I managed to find some documentation ${ }^{19}$ on Ivan Kralj and Marko Hummel who both served in the Habsburg armed forces.

${ }^{19}$ Chaplains from the aforementioned diocese who were mobilized into the Habsburg armed forces during the World War I will be probably presented in another paper, based on some recently discovered documents in the War Archives in Vienna. The focus of this paper is on the spiritual care in the Habsburg army, especially on presentation of life and work of two military chaplains, Marko Hummel and Ivan Kralj. 


\subsection{Military Chaplain Marko Hummel}

For the year 1850, Militärschematismus des österreichischen Kaiserthumes [sic!] of the Imperial Army does not include any information on military chaplains in its records on the military command in the individual places in Pavia, ${ }^{20}$ even though this function was performed by the priest Marko Hummel from the Diocese of Bosnia or Đakovo and Srijem since December 1849. Nevertheless, there is a record in Militärschematismus for 1851 that Marko Hummel was a garrison chaplain (Garnisons-Caplan). ${ }^{21}$

According to military records, Marko Hummel was born on April 25, 1818 in Kalocsa (Croatian: Kaloča). After his birth, the family moved to Đakovo where his father worked as a choirmaster at the diocese. In Đakovo, Hummel went to school, studied theology, and was ordained on April 29, 1841.22 Afterwards, he performed his religious services in various parishes for eight years, which was noted down as $\gg 8$ Jahre bei der Zivil-Seelsorge. ${ }^{23}$ Hummel was appointed military chaplain on October 22, 1849 and was sent to Pavia, Italy, as a garrison military chaplain. In particular, he provided spiritual care to soldiers who were admitted to the garrison hospital. He operated in Pavia for $\gg 1$ year, 7 months and 9 days «, as was noted down by the military officials in 1859. As a military chaplain he received an annual salary of 529 guldens, he was entitled to an accommodation, a personal attendant (Diener), and $2 / 3$ of 4 cubic metres of firewood in the wintertime in that year. Besides the superiors' evaluation, there are also some data on his language skills. According to the records, Hummel was fluent in Latin, German, Hungarian and »Illyrian «, while his Italian was $\gg$ mittelmäßig $\ll{ }^{24}$ His military career is thoroughly described in his military personnel records, which were written at the end of the 1880s.

On June 1, 1851, Marko Hummel was reassigned from Pavia and became the regiment chaplain of the third class of the fifth Uhlan ${ }^{25}$ light cavalry regiment, where

${ }^{20}$ Militärschematismus des österreichischen Kaiserthumes were always written in advance and thus could not include the most recent data.

${ }^{21}$ Militärschematismus des österreichischen Kaiserthumes (Wien: K. k. Hof - und Staatsdruckerei, 1851), p. 93.

${ }^{22}$ Österreichisches Staatsarchiv (ÖSTA)/Kriegsarchiv (KA), Qualifikationslisten (Quall), Karton 1177, Hummel Markus.

${ }^{23}$ ÖSTA/KA, Conduite-Listen (CL), Militärgeistlichkeit, Karton 858, Hummel Markus - Conduite-Listen 1859.

${ }^{24}$ Ibid.

${ }^{25}$ Uhlans were light cavalry armed with lances, sabres and pistols. At the beginning of 1914, the Habsburg Empire had 11 Uhlan regiments composed of mostly the Czechs, Ukrainians or the recruits of Polish nationality. There were two exceptions: Croats presented the majority in Uhlan regiments No. 5 and 11 . 
he worked until 1869 with one short intermission. For one month, he worked as a military chaplain within the military institution in Leutschau (today Levoča; Hungarian: Löcse), a town in present-day Slovakia, from where he returned to his regiment. He was promoted to a regiment chaplain of the second class on July 1, 1861. In 1863, he was sent to the $12^{\text {th }}$ Field Artillery Regiment for the period from November 1 to December 1, where he provided pastoral care until his return to the Uhlan regiment. ${ }^{26}$

In 1866, the Habsburg Monarchy was engaged in the war with Italy and Prussia. It is interesting that there is no information on Hummel's participation in the campaigns in the documents from the year 1867. In his later military personnel records, from 1887, it is recorded that Hummel was the military chaplain of units participating in fights against the Prussians. In his file, the battle on July 3, 1866, the famous Battle of Königgrätz (Czech: Hradec Králové), was especially emphasised. It can be discerned from the records that he was also a consistorial councillor of the Diocese of Bosnia or Đakovo and Srijem in 1866 at the latest. According to the records, Hummel could speak the following languages: $\gg$ Latein, Deutsch, Ungarisch und Illirisch $\left[\mathrm{sic} !{ }^{27}\right.$. Interestingly, there is no information on Hummel's knowledge of the Italian language in this record, which was mentioned in the document from 1859.

Despite the victories in Italy, the Austrian forces suffered a bitter defeat in the war against Prussia. On August 23, 1866, a peace treaty was signed in Prague, which signified the end of the Austrian supremacy in the German Confederation and the rise of Prussia. The consequence of this defeat was the reform or rearrangement of the Habsburg Empire, reforms in the Army and a new legislation. A part of these reforms was also the rearrangement of the spiritual care in the Armed Forces. ${ }^{28}$

\subsubsection{In a New Situation}

The reorganization of military clergy was passed by virtue of the highest decision on January 3, 1869 and was published in the Official Gazette of the Imperial Armed Forces on January 15, 1869. An article titled $\gg$ Duhovna pastva vojna $\ll$ on the decision and the new arrangement of the spiritual care in the Army was published in Zagrebački katolički list on March 4, 1869. ${ }^{29}$ The same newspaper reported about the basic changes and rearrangement even before, in December 1868. At that time, they wrote that 88 priests will not be active in the military anymore. ${ }^{30}$

\footnotetext{
${ }^{26}$ ÖSTA/KA, CL, Militärgeistlichkeit, Karton 859, Hummel Markus - Conduite-Listen 1867.

${ }^{27}$ ÖSTA/KA, Quall, Karton 1177, Hummel Markus.

${ }_{28}^{8}$ Šimac, Vojaški duhovniki, pp. 44-45.

${ }^{29}$ Zagrebački katolički list, March 4, 1869, pp. 68-70.

${ }^{30}$ Ibid., December 31, 1868, p. 424.
} 
In compliance with the decision, they rearranged the spiritual care in the Army, abolished the regimental military chaplains, military superiorates and superiors, and introduced military parishes with military parish priests (Militärpfarrer) to replace them. The Dual Monarchy was at first divided into 17 military territorial districts. In accordance with the division, every district had its own military parish (Militärpfarramt), headed by a military parish priest. At the time, the seats of military parishes were located at the seats of military districts. ${ }^{31} \mathrm{~A}$ military parish priest was, just like his predecessor superior, responsible for the operation of military clergy in his area.

Prior to 1871 , military chaplains were divided into three classes, and after this time only the military chaplains of the first and second class remained. In 1871, they introduced another function besides the military chaplain, namely a military curate. ${ }^{32}$ Military curates were also divided into two classes and they provided spiritual care to the military members, either in garrison hospitals and garrisons or in other military institutions. ${ }^{33}$

\subsubsection{Offices}

Since regiment military curates were abolished on February 1, 1869, Marko Hummel was promoted to the rank of a military curate of the first class and reassigned to the garrison hospital No. 21 in Timisoara (Temišvar)..$^{34}$ This reassignment was also mentioned in a special supplement of the newspaper Fremden-Blatt on January $30,1869 .{ }^{35}$

Hummel worked at the garrison hospital only for a short time, less than two full months, and then he was sent to Arad (today in Romania), where he stayed until February 1, 1872. In addition to the garrison, he was also in charge of the military hospital in Klein-Szent-Miklos. In February, he was reassigned back to Timisoara,

${ }^{31}$ K. K. Armee Verordnungsblatt, Normal-Verordnungen, January 15, 1869, Die Militär-Seelsorge (Wien: Kaiserlich-königlichen Hof und Staatsdrukerei), pp. 2-3. At the time, these were located in the following towns of the Dual Monarchy: Vienna, Linz, Graz, Trieste, Innsbruck, Brünn (today Brno), Prague, Krakow, Lemberg (today L’viv), Zadar (Zara), Buda (Ofen), Zagreb (Agram), Košice (Kaschau), Bratislava (Pozsony/Preßburg), Petrovaradin (Peterwardein), Temesvár (today Timișoara in Romania), Hermannstadt (today Sibiu, Romania). See also: Kirchliches VerordnungsBlatt für die Laibacher Diözese, (Laibach, 1870), Nr. XXIV, p. 155.

${ }^{32}$ Cf. Bielik, Geschichte der k.u.k. Militär-Seelsorge, p. 172, p. 212.

${ }^{33}$ Ibid., p. 210.

${ }^{34}$ ÖSTA/KA, Quall, Karton 1177, Hummel Markus.

${ }^{35}$ Fremden-Blatt, January 30, 1869, I. Beilage des $\gg$ Fremden-Blatt $\ll$. 
where he worked until November 1, 1875, when he was sent to Graz. ${ }^{36}$ On October 29, 1875, the Graz newspaper Grazer Volksblatt reported that Marko Hummel, a military curate of the first class from the garrison hospital No. 21, was appointed military parish priest in Graz. ${ }^{37}$

The appointment of a military parish priest was, similarly to that of a military superior before, a matter of procedure, although the proposal of Apostolic Field Vicariate had to be sent for confirmation not only to the Imperial War Ministry but also to the Emperor, which was the only difference in the appointment procedure. ${ }^{38} \mathrm{Hum}$ mel was responsible for the operation of all clergy in the area of Graz General Commands. He worked there for only a year, then he served as a military parish priest in Bratislava (Pressburg) from 1877 to 1883 and in Budapest from 1884 onwards. It is interesting that, in 1887, he was honoured by the Emperor for his exemplary performance and became a titular provost $\gg$ zum Heil. Ladislaus von Semlin «. On November 16, 1888, he received a decoration, the Knights' Cross of the Order of Franz Joseph, by the Emperor for long-time religious services. ${ }^{39}$ There is a notice on Hummel's decoration in the newspaper Wiener Zeitung from December 1, 1888: »in Anerkennung seiner langen, berufstreuen und ersprießliechen Dienstleistung das Ritterkreuz des Franz Joseph Ordens zu verleihen. $\ll{ }^{40}$

\subsubsection{Marko Hummel in Evaluations of Military Authorities}

To gain a broader insight of Hummel's life and work, we researched the so-called military »personnel records «, which were written in 1887 by military authorities. Twelve columns reveal the data about his rank, language skills (Sprachkenntnisse), character, and his attitude towards other people in his free time and while on duty. The data on his language skills reveal that the military parish priest Marko Hummel fluently spoke, read, and wrote German, Hungarian, Croatian, and Latin. As much as needed for the performance of his duties, he could speak Italian and some French. He had a calm temperament and his character was described as noble and utterly honourable. He was an excellent preacher, trustworthy and precise about keeping records on deaths and other military records. In the column about his zeal on duty, it is written that he performed his duties in the best possible manner, his eagerness could be discerned from his willingness for further education. In relation to his superiors, Hummel was obedient, kind to those of equal rank, and consistent

\footnotetext{
${ }^{36}$ ÖSTA/KA, Quall, Karton 1177, Hummel Markus.

${ }^{37}$ Grazer Volksblatt, October 29, 1875.

${ }^{38}$ Šimac, Vojaški duhovniki, p. 47.

${ }^{39}$ ÖSTA/KA, Quall, Karton 1177, Hummel Markus.

${ }^{40}$ Wiener Zeitung, December 1, 1888, p. 1.
} 
towards his subordinates; he knew how to maintain order and discipline and at the same time gain their trust.

Hummel's physical description reveals that he was of average height, slim, healthy and firm, but, as was added, considering his age, he could only perform less demanding work in the time of war. ${ }^{41}$

By means of the aforementioned records, we gained a deeper insight into the life and work of the military chaplain Marko Hummel, who was similarly evaluated in the following years. The last entry suggests that he should consider retiring in the near future.

In 1891, the military parish priest Marko Hummel celebrated the $50^{\text {th }}$ anniversary of priesthood, which was also published in a newspaper. On May 8, 1891, Pester Lloyd reported that on the previous day the military parish priest Hummel celebrated his anniversary by reading at the nine o'clock morning mass at the Budapest garrison church. All Budapest generals attended the mass, including the corps commander, Prince Rudolf Lobkowitz, and the representatives of all regiments stationed there. ${ }^{42}$ This was Hummel's swan song, his farewell to the military service. From the 1891 records, we learn that he had some health problems at the time. ${ }^{43}$ Hummel was aware of his medical condition and thus retired in April 1892. Upon his retirement, he received the Military Merit Medal (Militärverdienstmedaille) or Allerhöchste Zufriedenheit for his loyal long-time service that was given for exceptionally exemplary service in the time of piece. ${ }^{44}$

Marko Hummel, a retired military chaplain, consistorial counsellor of the Diocese of Bosnia or Đakovo and Srijem, and a titular provost spent his final years in Budapest where he died on August 5, 1898. ${ }^{45}$ Even though he never performed religious services in his diocese, he honourably represented the clergy of the Diocese of Bosnia or Đakovo and Srijem as a military chaplain in the Armed Forces.

\subsection{Military Chaplain Ivan Kralj}

Hummel's exemplary career as a military chaplain might have been an inspiration for other priests who wanted to dedicate their life and work to the spiritual care of soldiers in the Imperial Armed Forces.

\footnotetext{
${ }^{41}$ ÖSTA/KA, Quall, Karton 1177, Hummel Markus.

${ }^{42}$ Pester Lloyd, May 8, 1891, p. 7.

${ }^{43}$ ÖSTA/KA, Quall, Karton 1177, Hummel Markus.

${ }^{44}$ Neuigkeits Welt Blatt, April 10, 1892, p. 3.

${ }^{45}$ Jarm, Dijecezanski svećenici, p. 135.
} 
Military officials noted that Ivan (Johann) Kralj, a priest of the Diocese of Bosnia or Đakovo and Srijem, was born on December 9, 1862 in Zagreb, as a son of a bourgeois and a house owner Josef Kralj and his wife Marija, born Edle von Rüpp. First, he studied theology in Zagreb, and then he moved to Đakovo, where he completed his studies and was ordained in 1887. At first he worked as a chaplain in the Parish of Semeljci and later in the Parish of Kopanica. ${ }^{46} \mathrm{He}$ expressed his wish to join the Armed Forces to Bishop Josip Juraj Strossmayer (1815-1905) who actually appointed him as a military chaplain. In the appendix of the document, there is a table where the Bishop explicitly emphasises Kralj's wish for religious services in the Armed Forces: $\gg$ Der Betreffende wünscht sehr und bittet um die Ausstellung in der aktiven Militärseelsorge. « The table includes some other data on Ivan Kralj; we also learn that he was fluent in Latin, German, and Croatian. ${ }^{47}$

A complete documentation on the candidate for an active military chaplain was sent to the military bishop on July 19, 1889. Bishop Strossmayer turned to the Military Bishop Anton Josef Gruscha (1820-1911). Since such letters are not always preserved, we decided to include the transcript of the German original, including various mistakes and language features, ${ }^{48}$ written by Bishop Strossmayer on August 17, 1889:

\section{»Euer Bischöflichen Gnaden!}

Laut hiesigen Ersuchens von 22. März 1. J. No. 323 und in Folge sehr verehrten Schreibens Euer Bischöflichen Gnaden von 19. Juli 1. J. No. 2719 beehrt sich dies bischöfliche Ordinariat diensthoflichst Euer Bischöflichen Gnaden als k. k. Apostolischen Feldvicar behuf Anstellung als Militär Kaplan II. Classe im Activ Stande der Militär Geistlichkeit seinen Dioecesan Weltpriester Johann Kralj derzeit Caplan in Kopanica vorzulegen mit der Bitte, dessen Ernennung beim Hohen k. k. Kriegsministerium gnädigst bewirken zu wollen. Benannter Priester ist der deutschen und croatischen Sprache in Schrift und Wort vollkommen mächtig, eines seinen $u$. artigen Benehmens und hegt den heißen Wunsch in der löb. Armee Seiner k. k. Majestät zu dienen.

Im Anschluße liegt bei die National und dienstbeschreibungs Tabelle des benannten Priesters.

\footnotetext{
${ }^{46}$ ÖSTA/KA, Quall, Karton 1528, Kralj Johann.

${ }^{47}$ ÖSTA/KA, Apostolische Feldvikariat (AFV), Karton 272, Kralj Johann.

${ }^{48}$ I would like to thank Jure Volčjak, $\mathrm{PhD}$ and Mira Miladinović Zalaznik, PhD for their help with transcripts and translations of German texts.
} 
Auch bei dieser Gelegenheit beehrt sich diess bischöfliche Ordinariat Euer Bischöflichen Gnaden seinen innigsten Dank auszusprechen für die besondere Liebe, die Sie so oft schon zur Geistlichkeit dieser Dioecese bekundet haben.

Djakovar am 17. August 1889.

Josip Juraj

Bischofm.p. ${ }^{49}$

The letter comprises all the basic information and data that are detailed and specified in the appendix: from Kralj's former religious services to his expressed wish to join the Imperial Armed Forces. At the end of the letter, Strossmayer especially thanked the Military Bishop for the affection he clearly showed towards the Diocese of Bosnia or Đakovo and Srijem.

Based on requests and recommendations, on November 5, 1889 Ivan Kralj was appointed active military chaplain of the second class and was assigned to the Graz Military Parish, from where he was sent to Marburg (today Maribor in Slovenia). He stayed there for only a year, since on November 1,1890 he started discharging his duties in the Military Parish of Zadar, where he also worked as a catechist (Religionslehrer) in the Military Elementary School (k.u.k. Militär-Volksschule).$^{50}$

However, it seems that Kralj encountered some difficulties in Zadar and he also had some health problems. On October 25, 1892 the military parish priest Johann Bauer from Zadar informed the Military Command that Ivan Kralj had fell sick and would be absent for at least three months. Since there was a lot of work, he requested they send a substitute priest who spoke German and Croatian to Zadar for the time of Kralj's absence. The following day Bauer informed the Apostolic Field Vicariate about Kralj's sickness, described the situation and requested for a Croatian speaking priest. The spiritual care had to be provided to soldiers at a military hospital, garrison prison and other institutions. ${ }^{51}$

It can be discerned from the preserved medical report that a medium built 30-yearold military chaplain had difficulties with the serous fluid (hydrocele). Kralj's health problems continued in the upcoming months. The new military parish priest Heinrich Kranjec stated on March 18, 1893 that on that day Kralj reported in sick and would have to visit the Viennese Hospital No. 1, where he might undergo a surgery. He reported as healthy and ready to work only on August 24, $1893 .{ }^{52}$

\footnotetext{
${ }^{49}$ ÖSTA/KA, AFV, Karton 272, Kralj Johann.

${ }^{50}$ ÖSTA/KA, Quall, Karton 1528, Kralj Johann.

${ }^{51}$ ÖSTA/KA, AFV, Karton 272, Kralj Johann.

${ }^{52}$ Ibid.
} 
Kralj worked in the Military parish of Zadar until November 1, 1895, when he was reassigned to Sarajevo, where he remained until 1900. At first, he worked in the Military parish of Sarajevo, but from 1897 onwards he performed his duties in Trebinje and Banja Luka. The following year, he still worked as a military chaplain in Banja Luka and, at the same time, he taught catechism in Foča. ${ }^{53}$

The end of 1898 was especially stressful for Kralj because, following a short illness, his father passed away in Zagreb. On November 7, 1898 the Agramer Zeitung published a notice that the previous day the house owner Josef Kralj died at the age of 66. His death was mourned by his three sons, the military chaplain Ivan, the pharmacist Stefan (Stephan), and $\gg$ the magistrate draftsman (Konzipist) N. Kralj. $\ll^{54}$

On April 29, 1900 Ivan Kralj was promoted to military chaplain of the first class. On November 21 of the same year, he was transferred to the Zagreb Military District (Bezirk). From February 19 to June 24, 1904 he provided religious services at the Garrison Hospital No. 23 in Zagreb and was exposed to Petrovaradin (Peterwardein) as a military curate. ${ }^{55}$

Ivan Kralj's military personnel records were supplemented yearly, all columns were filled in, even though we often come across the notation »as in the previous year «. Therefore, Kralj's personnel records from 1900 are the only ones presented here, since all later notations refer back to this year.

In 1900 the military priest Kralj was still a military chaplain of the first class, fluent in the German and Croatian language. Interestingly, Latin was only mentioned when he entered the active military service. He never served during a conflict with an enemy, as was written by his superiors, but they did evaluate his professional and off-duty attitude toward his superiors. According to his physical description, Kralj was fairly tall and strongly built, he had a strong and honest character, was kind-hearted, and of a merry temperament. They wrote that he was a good preacher, and that his sermons were attractive and adjusted to the religious needs of his listeners. He was sympathetic, he comforted the sick and was reliable, as well as skilled at keeping registers. In the column about his zeal on duty it is written that $\gg$ in the performance of his function he is eager and hard-working due to the love and interest for his profession. « While on duty, he was obedient and honest with the superiors, kind and obliging to those of equal rank, and his attitude toward subordinates was appropriate, thus he enjoyed their trust. Off-duty, he was described as a man who lived an impeccable moral life and liked spending time in

\footnotetext{
${ }_{53}$ ÖSTA/KA, Quall, Karton 1528, Kralj Johann.

${ }^{54}$ Agramer Zeitung, November 7, 1898.

${ }^{55}$ ÖSTA/KA, Quall, Karton 1528, Kralj Johann.
} 
officers' corps and clergy circles (führt einen tadellosen Lebenswandel, bewegt sich gerne im Kreise des Officiers-Corps und der Geistlichkeit). He was evaluated as suitable for any pastoral service in the times of peace or war. Kralj's military personnel records for this year were signed by his superior officer, the military parish priest Matija Rihtarić from the Zagreb Archdiocese.

However, it seems that military parish priest Rihtarić had a particular opinion of Kralj, based on several official complaints and procedures against him that he allegedly behaved improperly in Petrovaradin. Among other things, he supposedly forgot to salute his superior Major General in civilian clothes. In a letter to his friend, most probably a consistorial counsellor of the Apostolic Field Vicariate and later Military Bishop Emmerich Bjelik ${ }^{56}$ (1860-1927), as it is assumed from the writing, Rihtarić reported thoroughly on the military chaplain in Petrovaradin. There is a transcription of the letter (with no date of writing), including mistakes and language features, which was written in the German language:

\section{$\gg$ Lieber Freund!}

Betreff des Militär-Caplans in Peterwardein bin ich verpflichtet Dir nun folgendes mitzutheilen:

Wie ich Dir vor einigen Wochen berichtete, ist vom Herrn Brigadier, dem G(eneral) M(ajor) Sandmann in Peterwardein gegen denselben eine Anzeige erstattet worden, daß er am 19. Juni 1. J. den Milt. Caplan Kralj im ganz verwahrlostem Zustande, als einen der die ganze Nacht durchschwärmt hatte, um $6 \mathrm{Uhr}$ früh an der Hand eines Civilisten in ein Gasthaus wanken gesehen hatte. Wenn ich den Kralj gar nicht Tage vorher, als einen ganz anständigen Geistlichen, und zwar auf Relation des mir gut bekannten griech. kath. Dechants u. Pfarrers in Ujvidék, Dir geschildert und gebeten hätte, wenn derselbe nach Agram versetzt würde, ich nichts dagegen hätte: ich hätte die obige Anzeige nicht sofort Dir zur Kenntniß gebracht, - und es wäre auch besser gewesen; denn die Sache hatte einen ganz anderen Verhalt, als ich anfangs geglaubt hatte.

Der Herr ergl Militär-Seelsorger Moór war dienstlich in Peterwardein anwesend, und war sammt dem geist. Pfarrer Kvacsák tags vorher beim Kralj zum Abendessen eingeladen. Sie besprachen sich dabei, anderen Tag früh sich in Ujvidék sich zu treffen, dort zu frühstücken und den

${ }^{56}$ The surname Bielik is spelled differently in various sources, as $\gg B i e l i k \ll$ on the book cover and as $\gg$ Bjelik « in the archival records and letters he sent. Therefore, I used $\gg B j e l i k \ll$ in the text and $\gg B i e-$ lik« when referring to his book Geschichte der k.u.k. Militär-Seelsorge und des Apostolischen Feld-Vicariates. 
Herrn Moór auf die Bahn zu begleiten. Der Herr Moór hat sich darauf in seine Wohnung nach Neusatz begeben, Kvacsák ist aber - um nicht nach Kamenitz zu gehen, beim Kralj schlafen geblieben. Als die zwei den anderen Tag nach Ujvidék gegangen sind, war Herr Moór ihnen bereits entgegen gegangen; sie trafen sich auf der Gasse, und gingen alle drei ins Gasthaus 'Mayer' zum Frühstück. In demselben Gasthaus hat aber der Herr G. M. Sandmann, der übrigens in Peterwardein wohnt, zu gewissen Zwecken ein Zimmer. In einem schwarzen Civilrock gekleidet, schaute derselbe übers Fenster hinunter, als die drei eben im Begriffe waren ins Gasthaus zu gehen. Der Herr Kralj sagt, er habe ihn zwar gesehen, aber nicht begrüßt, und dies, meint er, wird der Grund jener falschen Anzeige gewesen sein.

Die Anzeige würde, behufs Abnahme der Äußerung vom Herrn Kralj, dem Festungs-Commando in Peterwardein übergeben. Der Kralj berief sich auf beide Collegen, daß er die ganze Nacht zu Hause geschlafen hat, und in einem ganz anständigen Anzuge gewesen sei; und nachdem diese beide seine Collegen bestätigt hatten, wurden alle diese drei Äußerungen dem Herrn G. M. Sandmann übersendet mit folgendem Indossat: 'zur Kenntnißnahme mit dem Beifügen übermittelt, daß ich die instehende Angelegenheit hiemit als abgeschloßen betrachte, (und Euer Hochwohlgeboren Ihre voreilige und unüberlegte Anzeige ausstellig zu bemerken befunden habe).' Doch die in Clammern gesetzten Worte, welche der Herr Justiz-Referent geschrieben hat, hat Seine Excellenz der Herr Corps-Commandant gestrichen und die Bemerkung beigesetzt: 'werde ich persönlich mittheilen.' Klobus m. p.

Beiliegende Ergänzung zur Äußerung des Militär Caplan Kralj, welche mir vom Corps-Commando rückgeschloßen worden ist, sende Dir zur Einsicht.

So wird der Wahrheit zu lieb. In einem Briefe sagt mir der Kralj folgendes: 'Daß ich hier mit den Geistlichen und nicht mit den Officieren umgehe, ist meine Sache, die niemanden angeht; ich weiß warum ich dies thue. Darüber könnte meine Geldtasche manches erzählen. Ihre Gesellschaft und ihre Freundschaft kostet mich viel; und solange ich ein Narr war, wie ich faktisch gewesen bin, war ich ein 'fescher', 'netter' und 'echter' Militär Kaplan; und so bin ich ein Pfaff und dazu ein 'verwahrloster.'

Betreff des Dr. Senjak war ich noch nicht vorgeladen; er droht mir, daß er nun gegen mich auftreten wird. Unlängst hat sich der Herr Platz-Commandant bei mir über sein Benehmen in der Platz-Commando-Kanzlei, 
sehr beschwert. 'Um ihm nicht zu schaden,' hat er keine Anzeige darüber ans Corps-Commando erstattet.

Ich meine, Seine bischöfliche Gnaden nehmen dies nicht übel, daß ich über diese Gelegenheiten mit Dir in Verbindung stehe, und nicht Seiner Gnaden es directe vorlege, da Du ohnedies Sekretär bist.

Habe die Güte, Seiner Gnaden meinen ehrfurchtsvollen Handkuß auszurichten, und bleibe wohlwollend Deinem Akten

\author{
Math. Rihtarić \\ Mlt. Pfr. $\ll^{57}$
}

Rihtarić reported on the hearing of the military curate Kralj following the appeal of Major General Emil Sandmann, the commander of the $14^{\text {th }}$ Infantry Brigade in Petrovaradin (Peterwardein). The major general described that on June 19, at six o'clock in the morning, he saw Kralj, who seemed unkempt, as someone who was drinking all night, entering an inn, where Sandmann was residing. But this appeal, as noted by Rihtarić, obviously had a different, special intention of discrediting. Kralj believed, as Rihtarić wrote in a letter, that the appeal against him was filled because the major general, wearing civilian clothes, saw him at the inn: $\gg$ Mister Kralj says that he did see him but did not greet him, which might, as he believes, be the reason for that false statement.«

The command in Petrovaradin considered the appeal and denied the accusations after the hearing of witnesses and Ivan Kralj himself. The command's opinion is evident from the remark, $\gg$ the major general's report was made hastily and recklessly.« From Kralj's explanation to Rihtarić, we can make an assumption on the hidden reason for the appeal: »That I communicate here with the clergy and not with the officers is my business that concerns no one; I know why I do it. My valet could say a lot about that. Their company and their friendship are very expensive for me; and while I was an idiot, which in fact I was, I was 'great,' 'nice' and 'a true' military chaplain; and so now I'm a far and on top of that unkempt. « This record presents an interesting insight into the then situation in the Petrovaradin (Peterwardein) garrison, as it clearly depicts the attitude of high-ranking officers toward the military clergy. On the basis of Kralj's written statement to Rihtarić, we can ascertain that there were certain disagreements among the commanding officers themselves. ${ }^{58}$

The presented atmosphere probably influenced Ivan Kralj's decision to start thinking about leaving the Army. In 1905, his military personnel records were supple-

\footnotetext{
${ }^{57}$ ÖSTA/KA, AFV, Karton 272, Kralj Johann.

${ }^{58}$ Ibid.
} 
mented for the last time. The repetition of the previous evaluation did not suffice for a promotion, nor his personal satisfaction. Ivan Kralj thus left the Army ${ }^{59}$ in 1906 and was incardinated into the Zagreb Archdiocese. In October 1906, the Agramer Zeitung reported: $\gg$ Der Geistliche der Djakovoer Dioezese, k.u.k. Militarkurat in Agram Ivan Kralj, wurde in den Klerus den Agramer Erzdioeceze uebernommen und zum Pfarrer in Stenjevec ernannt. $\ll{ }^{60}$ If Kralj wanted to be appointed a parish priest, he had to pass a parish exam. As it is revealed in the military documents, he successfully (Mit Sehr Gutem Erfolge) passed it in Đakovo in 1902. ${ }^{61}$

Ivan Kralj pursued his career as a priest in Stenjevec, where he passed away on September $27,1926 .{ }^{62}$

\section{Conclusion}

During the research of archival records and documents in the War Archives in Vienna, I came across the documentation presenting the life and work of military chaplains Marko Hummel and Ivan Kralj from the Diocese of Bosnia or Đakovo and Srijem who served in the Armed Forces of the Habsburg Empire. Despite the restless times, Hummel performed religious services up to his retirement, constantly striving for progress and promotion. A younger Ivan Kralj served in the Army during the time of increasing inner struggles within the Habsburg Empire and national movements, which were sometimes reflected in the relations among officers and soldiers. He was also prompted to leave the Army much sooner by virtue of circumstances, which at the beginning of the $20^{\text {th }}$ century were much different than at the time when Marko Hummel performed his services. The successes and difficulties of the two Slavonian priests Marko Hummel and Ivan Kralj clearly illustrate that they experienced very different career paths within the same Army. This paper briefly outlines the military clergy on the basis of a few documents from the War Archives in Vienna (unfortunately, memoirs, war diaries or correspondence of the aforementioned military chaplains have not been found yet) and gives insight into a small part of the Croatian church history that might motivate other Croatian historians and experts to thoroughly research the topic by means of archival records and documentation of the War Archives in Vienna and other sources.

\footnotetext{
${ }^{59}$ During the research, Kralj's war diaries or correspondence that would clarify the life and work of the military curate who served in the Imperial Army at the turn of the $20^{\text {th }}$ century were not found. For the time being, the paper could only present information and data from the archival records and documentation.

${ }^{60}$ Agramer Zeitung, October 12, 1906, p. 3.

${ }^{61}$ ÖSTA/KA, Quall, Karton 1528, Kralj Johann.

${ }^{62}$ Jarm, Dijecezanski svećenici, p. 169.
} 


\title{
HRVATSKI VOJNI KAPELANI MARKO HUMMEL I IVAN KRALJ U SVJETLU ARHIVSKIH ZAPISA RATNOGA ARHIVA U BEČU
}

\author{
Miha ŠIMAC*
}

Sažetak: Nekoliko arhivskih zapisa i dokumenata u Ratnom arhivu u Beču prikazuju život $i$ rad vojnih svećenika u habsburškim oružanim snagama. U radu je prikazan život i rad vojnih kapelana iz Đakovačke ili Bosanske i Srijemske biskupije Marka Hummela i Ivana Kralja, koji su djelovali u habsburškim oružanim snagama. Marko Hummel pridružio se spomenutim oružanim snagama sredinom 19. stoljeća i obavljao je vjerske službe sve do umirovljenja, dok je Ivan Kralj služio u vojsci znatno kraće vrijeme, jer je navodno imao problema s nadređenima i zbog okolnosti na koje je naišao u Petrovaradinu (Peterwardein). Glavna je svrha ovoga rada malo rasvijetliti dio hrvatske crkvene povijesti koji se često zaboravlja i nadam se potaknuti daljnja istraživanja.

Ključne riječi: Austro-Ugarska, vojno svećenstvo, Đakovačka ili Bosanska i Srijemska biskupija, Ivan Kralj, Marko Hummel, Ratni arhiv, Beč.

* Doc. dr. sc. Miha Šimac, Teološki fakultet Sveučilišta u Ljubljani, Poljanska cesta 4, p. p. 2007, 1001 Ljubljana, Republika Slovenija, miha.simac@teof.uni-lj.si 